\begin{tabular}{|c|c|c|c|c|}
\hline Submission & Review Process & Revised & Accepted & Published \\
\hline $23-09-2020$ & $25-09$ s/d 24-11-2020 & $27-12-2020$ & $30-12-2020$ & $31-12-2020$ \\
\hline
\end{tabular}

Jurnal Studi Sosial dan Politik, Vol. 4, No. 2, December 2020 (109-121)

ISSN 25978756

e ISSN 25978764

Jurnal Studi Sosial dan Politik Published by: FISIP Universitas Islam Negeri Raden Fatah Palembang

\title{
ASEAN Community and Prospects for the Development of UIN Raden Fatah Palembang
}

\author{
Aflatun Muchtar \\ Faculty Dakwah dan Ilmu Komunikasi UIN Raden Fatah Palembang \\ Email: aflatunmuchtar2019@gmail.com \\ Aristophan Firdaus \\ Fakultas Ushuluddin dan Pemikiran Islam UIN Raden Fatah Palembang \\ Email: topan22.rs@gmail.com
}

\begin{abstract}
By entering the era of higher education industrialization, Indonesia is required to improve itself so that it can compete with other ASEAN countries. According to several university ranking data, the quality of Indonesian education is still below Singapore and Malaysia. The portrait of the quality of Indonesian higher education is still very vulnerable to injustice and lack of equity.

Competition for a professional workforce, having mature skills and being equipped with good language skills are prerequisites for competing fairly with other ASEAN member countries. Of course, Raden Fatah State Islamic University Palembang, which has approximately 25,000 students consisting of 39 study programs and 500 lecturers, both domestic and foreign graduates, has great potential to be involved in preparing a reliable workforce in their fields. The quality of the workforce must be supported by the quality of education held in each country, including UIN Raden Fatah Palembang. With good quality, the country's human resources are ready to compete in the ASEAN labor market.

The factors that determine the effort to improve the quality of UIN Raden Fatah Palembang in facing the ASEAN Community include: vision and mission; rules; governance guidelines; student body; human Resources; infrastructure; Tri Dharma College; international cooperation; visiting lecturer; and Asean issues. All of these factors are the basis for higher education management.
\end{abstract}

Keywords: ASEAN community, world class university, research university 


\begin{abstract}
Abstrak
Dengan masuk era industrialisasi perguruan tinggi, maka Indonesia diwajibkan untuk membenahi diri agar dapat bersaing dengan negara negara lain ASEAN. Menurut beberapa data perangking Universitas, kualitas Pendidikan Indonesia masih di bawah Singapura, dan Malaysia. Potret kualitas pendidikan tinggi Indonesia masih sangat rentan dengan ketidakadilan dan kurangnya pemerataan.
\end{abstract}

Persaingan tenaga kerja yang professional, memiliki skill yang matang serta dilengkapi dengan kemampuan bahasa yang baik menjadi prasyarat untuk bersaing secara sehat dengan negara anggota ASEAN lainnya. Tentunya Universitas Islam Negeri Raden Fatah Palembang yang memiliki kurang lebih 25.000 mahasiswa terdiri dari 39 Program studi dan 500 dosen baik lulusan dalam maupun luar negeri memiliki potensi besar untuk terlibat dalam menyiapkan tenaga kerja yang handal di bidangnya. Kualitas tenaga kerja harus didukung dengan kualitas pendidikan yang diselenggarakan di masing-masing negara termasuk UIN Raden Fatah Palembang. Dengan kualitas yang baik, maka sumber daya manusia negara tersebut siap bersaing dalam pasar tenaga kerja ASEAN.

Faktor yang menentukan dalam upaya meningkatkan kualitas UIN Raden Fatah Palembang dalam menghadapi ASEAN Community antara lain : visi dan misi; aturan; pedoman tata kelola; student body; sumber daya manusia; infrastruktur; tri dharma perguruan tinggi; kerjasama internasional; visiting lecturer; dan isu Asean. Seluruh faktor tersebut merupakan dasar dalam pengelolaan perguruan tinggi.

Kata kunci: ASEAN Community, world class university, research university

\title{
INTRODUCTION
}

ASEAN which was founded in 1967 in Bangkok met its special momentum with the initiation of the ASEAN Community (ASEAN Community) in 2015. One of the goals established by ASEAN is to accelerate economic growth, social progress and regional cultural development as well as promote regional peace and stability through respect for justice and the rule of law. Based on 2006 data, the ASEAN region has a population of 560 million with an area of 4.5 million square kilometers and a total trade of US \$ 1,400 billion.

ASEAN Community aims to assure that the purpose of the founding fathers of ASEAN in improving people standard of living to be implemented in economic developing and regional culture, social progress, regional peace and safety, collaboration, assistance among member of countries in training and research, improving standard of living, promotion in South East Asia study and cooperation with regional organization and International can be assigned well.

The implementation of ASEAN economic integration has led to the formation of the ASEAN Economic Community (AEC) which provides an ASEAN open and integrated market where there are more choices of products at prices that are of course fiercely competitive. The MEA initiative is also intended to support transnational market businesses and expand their market reach at lower costs through simplified cross-border trade through processes and an improved investment climate. At the same time, ASEAN economic integration is purposed not only through internal integration but also integration into the global 
economy and free trade in the future based on comprehensive economic partnership agreements and initiatives to increase the participation of global economic actors.

The ASEAN Community, of course, will have an influence on various sectors of life, including education. Education, which is increasingly competitive every year, the presence of the ASEAN Community will open the widest possible opportunity for foreign universities to enter and compete with universities in Indonesia and ASEAN member countries. This is a fact that the Indonesian government must immediately prepare everything to prepare adequate educational facilities and infrastructure so that Indonesian higher education does not sink amid the increasingly domination of foreign education. In addition, the government has also issued Law No.12 of Law 12/2012 on Higher Education which in article 90 states that universities in other countries can organize higher education in Indonesian territory in collaboration with universities in Indonesia and with government permission.

Higher education collaboration can be carried out between universities in ASEAN as has been formed in the Asian University Network (AUN) and several other universities that have collaborated with universities in ASEAN as well as with other countries in Europe and America.

Global competition in education has to pay attention on some points including: quality of graduate competence, International language skills in English, ability to work together, the results of research, the program implemented, the ability of the lecturers, and overall the quality of higher education should be properly and measured.

\section{RESEARCH METHODOLOGY}

This research is a qualitative study using a literature review approach that has a correlation with the research title. The data collection was carried out using two techniques, namely using the method of observation and interview techniques. Both techniques are used integratively and complement each other. Therefore, in conducting this research, several tools will be used, such as: interview guidelines, check list observation guidelines, and note book.

To obtain complete data, data sources are very important so that research produces the right understanding of conclusions. Sources of data according to Sutopo consist of sources (informants), events or activities, places or locations, objects, pictures, and recordings, and documents.

Observations and interviews were guided and developed by Spradley, starting with observations and descriptive interviews. Data collection was continued with focused observation and structural interviews, ending with selective observation and contrast interviews.

\section{RESULTS AND DISCUSSION}

\section{Opportunities and Challenges of UIN Raden Fatah in the ASEAN Community}

By entering and the era of higher education industrialization, Indonesia is required to improve itself so that it can compete with other ASEAN countries. According to several university ranking data, the quality of Indonesian education is still below Singapore and Malaysia. The 
portrait of the quality of Indonesian higher education is still very vulnerable to injustice and lack of equity.

This, we can learn from the quality of education in Germany which is so evenly distributed. The quality of Indonesian universities is expected to be able to compete in the global market, especially in the ASEAN region. For that, English language skills, teamwork or collaboration skills, innovation abilities, creativity, all need to be improved by going through the fast track program to improve the quality of academic quality and talent. The unemployment rate is quite high, reaching 300,000 people, reflecting the concern of university graduates in Indonesia who do not have the ability to enter employment opportunities. (Purba, 2015)

In a report submitted by the Organization for Economic Cooperation and Development (OECD) on higher education in Indonesia, it is stated that universities in Indonesia are considered lagging universities and find it difficult to compete, especially in the realm of the global labor market. A World Bank survey, which said, $20 \%-25 \%$ of university alumni in Indonesia must receive training before working. This means that graduates of state universities in Indonesia still need additional "supplements" so that they are ready to be put in the field.

The findings of Asiaweek 2000 show that the competitiveness of universities in Indonesia is low. Very few universities are able to enter the top 20 category in the Asian region. Of the 82 PTNs with 3051 study programs and 2561 private universities with 10287 study programs, it turns out that there are very few quality study programs.

There are still many Indonesian universities only targeting the quantity of students, opening new study programs, opening special classes such as employee classes, long-distance classes, week-end classes / Saturday-Sunday classes or executive classes. The college offers diplomas by attending these classes without emphasizing their quality. Such classes are not designed to achieve a prime quality, with condensed subjects, arbitrary (improvised) teaching, one-way delivery of material, without proper training or practice.

Palembang, as one of the cities that often hosts International events, should prepare its higher education human resources properly so that the formation of the ASEAN Community is used as a momentum to reorganize the city of Palembang, be it tourism, culture to qualified human resources. Several successful International events held in Palembang include; Sea Games 2011, Islamic Solidarity Games 2013, ASEAN Games 2018, MXGP 2019 and several other major events that have elevated the name of Palembang to the International level.

Of course, these opportunities need to be used as capital that in the future Palembang sill has great potential to hold bigger events. For this reason, in order to create great opportunities, it is not wrong that several universities in Palembang must help the local government to develop tourism and cultural potential and what is no less important is the potential of Palembang's human resources.

Competition for a professional workforce, possessing mature skills and good language skills is a prerequisite for competing fairly with other ASEAN member countries. Of course, Raden Fatah State Islamic University Palembang, which has approximately 25,000 students consisting of 39 study programs and 500 lecturers, both domestic and foreign graduates, has great potential to be involved in preparing a reliable workforce in their fields. The quality of the workforce must 
be supported by the quality of education held in each country including UIN Raden Fatah Palembang. With good quality, the country's human resources are ready to compete in the ASEAN labor market.

The quality of the workforce must be supported by the quality of education provided in each country. With good quality, the country's human resources are ready to compete in the ASEAN labor market. Likewise, if the quality of education is low, the human resources produced will find it difficult to compete in the labor market.

The governance of a university depends on factors that are integrated with one another. If one of the factors is not good, it will have an adverse impact on other factors and of course it will cause the governance of a university to be less good.(Nulhaqim, 2016)

The determining factors in efforts to improve the quality of higher education in facing the ASEAN Community include: vision and mission; rules; governance guidelines; student body; Human Resources; Infrastructure; Tri Dharma College; International cooperation; Visiting lecture; and Asean Issues. All of these factors are the basis for higher education management.

Lecturers in tertiary institutions who do very little research either related to academic development or market needs, unsupportive research funds provided by both the Ministry of Education and Culture and Ministry of Religion, reports that are normative in nature of administration that are so complex will certainly take the attention and time of educators or lecturers who should focus on research and teaching patterns to be delivered. Universities still have to be able to carry out their responsibilities in implementing the Tri Dharma of higher education so that they have the ability to solve various problems of the wider community because universities operate according to the needs and problems of social problems.

Based on the above objective conditions, it is time for higher education to have an important role in producing human resources who have global skills and knowledge. Higher education provides workers who have the abilities and competencies needed by the market. In addition, quality universities will also be able to produce leaders and thinkers of a nation who will determine the country's future development.

There are several things that need to be considered and implemented in the development process of UIN Raden Fatah Palembang so that the quality and management of higher education can be well organized.

- Curriculum and teaching practice in lecture halls

- Educational infrastructure and technology

- Partnership and Scholarship Program

- Lecturer career development through university scholarship programs and other institutions

○ Development and updating of university technology

- University business center that supports developers

- Career development of students who have graduated (output)

- Evaluate each program implementation 
If the quality assurance system in higher education does not contribute to the improvement or improvement of university development or does not have a positive impact on the learning system, it is necessary to carry out further innovation and research, because if it is not done it will only spend the budget unless the university is teaching only for ceremonial purposes only.

\section{Research}

Research conducted by UIN Raden Fatah Palembang, is expected to have an impact on the world through new insights that lead to cultural, social, political and economic changes. With global ambition but deep roots both locally and nationally as reflected in the motto of UIN Raden Fateh Palembang. In addition, investing further in infrastructure to facilitate regional, national and international collaboration, in the skills and people to provide the capacity for such collaboration, and engaging with other universities of course by maximizing the cultural, social and economic benefits derived from research regional, national, and International.

In terms of ranking, the position of PTKI universities under the Indonesian Ministry of Religion, especially those released by THE, UniRank and other institutions, is almost undetected.

According to the ranking released by Webometik, there are 10 best universities in Southeast Asia including one of them is the University of Indonesia which is ranked $9^{\text {th }}$. The following is the table: (https://www.kompas.com/tren/read/2020/08/03/180700665/10universitas-terbaik-di-asia-tenggara-versi-webometrics-ui-peringkat-9?page=all)

\begin{tabular}{|l|l|l|l|}
\hline No & University & Rank & Countries \\
\hline 1 & National University of Singapore & 1 & Singapura \\
\hline 2 & Nanyang Tecnological University & 2 & Singapura \\
\hline 3 & Universiti of Malaya & 3 & Malaysia \\
\hline 4 & Chulalongkorn University & 4 & Thailand \\
\hline 5 & Univeristi Teknologi Malaysia & 5 & Malaysia \\
\hline 6 & Universiti Sains Malaysia & 6 & Malaysia \\
\hline 7 & Universiti Putra Malaysia & 7 & Malaysia \\
\hline 8 & Mahidol University & 8 & Thailand \\
\hline 9 & Universitas Indonesia & 9 & Indonesia \\
\hline 10 & Chiang Mai University & 10 & Thailand \\
\hline
\end{tabular}

From the table above, universities in Malaysia dominate the ranking of the best universities in Southeast Asia. This means, from year to year, there have been serious efforts made by both the Malaysian government and university managers. Several Malaysian journals also slowly dominate in Southeast Asia as journals that have International reputation as evidenced by indexation in Scopus and ISI web of science.

As for the Asian level, none of the universities in Indonesia are in the top 100. Only UI has managed to enter the top 200 in 2020, which is at 162. The top 10 best campuses according to Time Higher Education are as follows: 


\begin{tabular}{|l|l|l|l|}
\hline No & University & Rank & Countries \\
\hline 1 & Tsinghua University & 1 & China \\
\hline 2 & Peking University & 2 & China \\
\hline 3 & National University of Singapore & 3 & Singapura \\
\hline 4 & University of Hongkong & 4 & Hongkong \\
\hline 5 & $\begin{array}{l}\text { The Hongkong University of Science } \\
\text { and Technology }\end{array}$ & 5 & Hongkong \\
\hline 6 & Nanyang Technological University & 6 & Singapura \\
\hline 7 & The University of Tokyo & 7 & Jepang \\
\hline 8 & Chinese University of Hongkong & 8 & Hongkong \\
\hline 9 & Seoul National University & 9 & Korea Selatan \\
\hline 10 & $\begin{array}{l}\text { University of Science and Technology of } \\
\text { China }\end{array}$ & 10 & China \\
\hline
\end{tabular}

There are several points that are assessed in this university ranking, the first is citations that have been written by lecturers at the relevant university, especially in journals that have high reputation. Apart from industry income, international views are also the next point considered by THE.

According to data released by the Ministry of Education and Culture, there are several PTKIN that have a good reputation, especially PTKIN which has accreditation A such as Syarif Hidayatullah State Islamic University Jakarta, Sunan Kalijaga State Islamic University Yogyakarta, Malik Ibrahim Malam State Islamic University, Sunan Ampel State Islamic University Surabaya and Sunan Kalijaga State Islamic University, Bandung.

According to data released by UniRank, the best PTKIN ranking is UIN Malik Ibrahim Malang which is in 26th position followed by UIN Syarif Hidayatullah Jakarta at 28th place. UIN Raden Fatah Palembang itself, according to the data above, is in $105^{\text {th }}$ place. The academic community of UIN Raden Fatah Palembang must make more serious improvements.

UIN Raden Fatah Palembang is the embryo for the establishment of several PTKINs in Sumatra. But on the other hand, it turns out that the "child" born by UIN Raden Fatah Palembang can grow and develop faster than the parent. Therefore, there is a big work and serious mapping that must be done by the academic community of UIN Raden Fatah Palembang.

In addition to the ranking carried out by several international credible institutions, Palembang, which is often used as an international event, must be used as a momentum by UIN Raden Fatah Palembang to promote, collaborate and develop the academic skills of UIN Raden Fatah Palembang, especially in facing the ASEAN economic community. In facing the ASEAN Community, UIN Palembang is expected to no longer only implement conventional education, but must demonstrate the inherent abilities and skills of graduates so that UIN Palembang graduates can compete in the ASEAN community. In increasing the competitiveness of graduates, UIN Palembang must be able to produce human resources who are competitive and useful and have independence. And of course this can be achieved if the infrastructure and supra structure of the UIN are adequate.

The institutional development carried out by the UIN Raden Fatah Palembang academic community in the last five years has been carried out through several channels, including through 
the Organization and Work Procedure (Ortaker) and the non-Ortaker route. Development through the Ortaker route includes:

1. Opening of 3 (three) faculties, namely:

a. Faculty of Social and Political Sciences (FISIP).

b. Faculty of Psychology.

c. Faculty of Science and Technology.

The three new faculties were inaugurated by the Minister of Religion of the Republic of Indonesia, Mr. Lukman Hakim Saifuddin, on July 72017.

2. Opening of New Study Programs

The new study programs that have been opened in the last five years include:

a. Biology Study Program

b. Chemistry Study Program

c. Physics Study Program

d. Mathematics Study Program

e. Political Science Study Program

f. Communication Studies Program

g. Early Childhood Islamic Education Study Program (PIAUD).

h. Madrasah Ibtidauyah Teacher Education Study Program (PGMI).

i. Zakat and Waqf Management Study Program.

j. Da'wah Management Study Program

k. Tasauf and Psychoteraphy Study Program.

1. Library Science

m. Islamic politics

n. Masters in Constitutional Law

o. Masters in Islamic Studies

p. S2 Syari'ah Economics

q. S2 Science of al Qur'an and Tafsir

r. Master of Islamic Education Management

s. Masters in Islamic History and Culture

t. S3 History of Islamic Civilization

As for the non-ortaker route, institutional development is carried out by forming new work units, namely:

1. Journal House

Journal House is an institution that was formed to accelerate the process of increasing the number and quality of journals in UIN Raden Fatah.

2. Malay Islamic Civilization Institute (MIC-Institute)

The Malay Islamic Civilization Institute (MIC-Institute) is an institution that was formed in order to accelerate the development of the study of Malay Islamic civilization, as one of the scientific distinctions of UIN Raden Fatah. 
3. Center for Pancasila and State Defense Studies

The Center for the Study of Pancasila and State Defense is an institution formed as a manifestation of one of the core values contained in the vision formulation of UIN Raden Fatah, namely "Indonesianness". This institution has a strategic role in instilling and disseminating the values of Pancasila and the spirit of State Defense among the academic community in particular and society in general.

\section{Educational Waqf Board}

The Education Endowment Center is an institution for managing funds or waqf assets whose use is devoted to the needs of education services and development, for example providing scholarships, provision of learning facilities, research, publishing books, and the like.

\section{Institute of Applied Psychology}

The Institute for Applied Psychology (LPT) is an institution managed by the Faculty of Psychology, as a 'practice facility for lecturers and students, to provide psychological services for people in need.

\section{Rafah TV}

Rafah Televisi, abbreviated as RafahTV, is a broadcasting institution managed by the Faculty of Da'wah and Communication as a training facility for students of the Islamic communication and broadcasting study program and means of socializing and publishing various academic and non-academic activities in the UIN Raden Fatah environment.

Improving the quality of human resources in the last five years has been carried out through the following programs:

1. Encourage and accelerate the lecturers' studies S3, by providing Study Permits (IB) and Study Assignments (TB).

2. Speed up the promotion process (see Table 3 and Graph 4).

3. Providing S3 Study Scholarships.

Starting in 2014, UIN Raden Fatah has provided 40 PhD Scholarships for lecturers. Of these 30 Scholarships have been absorbed and 17 of these scholarship recipients have passed the S3 study program at several domestic universities, 10 (ten) are in the process of completion, and 3 (three) have been declared Drop Out.

4. Providing recommendations for obtaining S3 study scholarships, especially scholarships from the LPDP and the 5000 doctoral program. In the last five years, the number of UIN Raden Fatah lecturers who received doctoral scholarships has increased from 0 to 15 people.

5. Organizing training, workshops, Focus Group Discussion (FGD), discussions and seminars, to improve the competence and professionalism of lecturers and staff. 
In addition to the above, several things have been done by the academic community of UIN Raden Fatah Palembang in order to prepare superior human resources in the ASEAN economic community through improving the quality and quality of journals in the scope of UIN Raden Fatah Palembang which initially had not been accredited at all then in 2020 it was already 27 journals that were accredited by Sinta, including 4 journals with Sinta 5 accredited, 13 journals with Sinta 4 accredited, 8 journals with Sinta 3 accredited, and two journals with Sinta 2 accredited.

To support quality journals, UIN Raden Fatah Palembang must also be able to produce quality research, especially in the field of religious sciences and those that support religious science. Viewed nationally, during the last 4 years from 2015 to 2019, the growth of Indonesia's international publications reached 263.27 percent. Indonesia's international publications in 2015 reached 8,263 scientific articles (ranked 4th in Southeast Asia). In 2016, the number increased by 48.79 percent to 12,295 scientific articles (ranked 4th in Southeast Asia). In 2017, Indonesia's international publications increased 64.61 percent to 20,239 (ranked 3rd Southeast Asia, beating Thailand). In 2018, with a growth of 48.31, Indonesia was finally able to rank 2nd in Southeast Asia, beating Singapore with the number of international publications reaching 30,017. In 2019, Indonesia targets to replace Malaysia as the Southeast Asian country with the largest number of international publications. Research policy support at the national level will certainly encourage progress in the field of research both carried out at state research institutes and at universities. In addition, support through a 30 percent funding scheme for BPOTN through the DIPA mechanism and an increase in the number of lecturers conducting research will answer the challenges and needs of research in the industrial era 4.0

In line with this, UIN Raden Fatah Palembang since 2015-2019 research has continued to increase funding and the amount of research. This is a form of commitment to improve the quality and quantity of national and international research. Total BOPTN Research Funds in 2017 amounted to 2.653 billion in 2018 amounting to 6.192 billion, in 20194.576 billion. The fund includes research quality improvement, methodology training, FGD, research support, and research technical guidance, proposal seminars, printed journals, printed guidelines, journal guidance, journal accreditation submission. BOPTN funds from 2017-2019 have indeed been fluctuating, however, the allocation of research funds for lecturers has increased quite significantly.

In sequence in 2017, UIN Raden Fatah Palembang received research funding allocation from BOPTN of IDR 2,653,000,000, 2018 of 6,192,000,000 and 2019 of IDR. 4,567,000,000 In 2015, the absorbed research budget for lecturers reached 360 million for 20 studies. In the following year, namely 2016, the research funds provided reached 112 million for 25 studies. Whereas in 2017 research funding increased significantly, reaching 2.524 billion for 172 studies, and there were 5 people who resigned. In 2018, research funds absorbed reached nearly 3.441 billion with 153 research titles. In 2019, 141 studies passed and 2 people withdrew from research funding of 3.755 billion.

Apart from going through the path of improving the quality of research, UIN Raden Fatah Palembang must also start promoting and be able to recruit foreign students. Until now, the foreign students netted by UIN Raden Fatah Palembang mostly come from Southeast Asia with the highest number of students from Malaysia, which is about 20 people, followed by Cambodia 5 people, 
Singapore 1 person and one student from South Korea who is currently pursuing a doctoral program in Civilization. Islam in the Postgraduate Program of UIN Raden Fatah Palembang.

To support the internationalization program of UIN Raden Fatah Palembang, as stated in the vision and mission of UIN Raden Fatah Palembang, it requires smart thinking and extra hard work to realize this dream. In these 2 years, the Indonesian Ministry of Religion has also recruited foreign students through the 5000 doctoral program. It is hoped that this momentum can be used as a foothold by the leadership of UIN Raden Fatah Palembang to ask the Indonesian Ministry of Religion to distribute 5,000 doctoral students to UIN Raden Fatah Palembang.

In addition to the steps above, the recruitment of foreign students can also imitate what has been done by universities from other countries such as Egypt, Iran, Libya during the time of Moammar Gaddafi who succeeded in recruiting foreign students to meet the needs of students from abroad

Some of the countries above only offer free tuition schemes, but the cost of living and housing is submitted to the respective students as well as universities offering full scholarships but with a relatively low monthly allowance.

With a pattern like that which has been carried out by several countries mentioned above, it is possible that UIN Raden Fatah Palembang can also do this provided that through a Rector decree either using the full scholarship scheme plus pocket money, the scholarship is only limited to free tuition or there are three options by giving foreign students a cheap UKT.

\section{CONCLUSION}

Palembang, as one of the cities that often hosts international events, should prepare its higher education human resources properly so that the formation of the ASEAN community is used as a momentum to reorganize the city of Palembang, be it tourism, culture to qualified human resources. Several successful international events held in Palembang include; Sea Games 2011, Islamic Solidarity Games 2013, ASEAN Games 2018, MXGP 2019 and several other major events that have elevated the name of Palembang to the international level.

Of course, these opportunities need to be used as capital that in the future Palembang still has great potential to hold bigger events. For this reason, in order to create great opportunities, it is not wrong that several universities in Palembang must help the local government to develop tourism and cultural potential and what is no less important is the potential of Palembang's human resources.

Competition for a professional workforce, having mature skills and being equipped with good language skills are prerequisites for competing fairly with other ASEAN member countries. Of course, Raden Fatah State Islamic University Palembang, which has approximately 25,000 students consisting of 39 study programs and 500 lecturers, both domestic and foreign graduates, has great potential to be involved in preparing a reliable workforce in their fields. The quality of the workforce must be supported by the quality of education held in each country, including UIN 
Raden Fatah Palembang. With good quality, the country's human resources are ready to compete in the ASEAN labor market.

The determining factors in efforts to improve the quality of higher education in facing the ASEAN Community include: vision and mission; rules; governance guidelines; student body; human Resources; infrastructure; Tri Dharma College; international cooperation; visiting lecturer; and Asean issues. All of these factors are the basis for higher education management.

Technology and human civilization are developing rapidly, therefore without adequate human resources a country will not progress. Challenges and opportunities that must be resolved by every country in the world, namely facing global competition that is so fast and complex. To get qualified human resources, every country is competing to improve its education level. In this case, it cannot be denied that universities play an important role in providing quality human resources, because university graduates are expected to have sufficient skills to be able to directly enter various fields of work in the world of global competition. But in reality, the quality and budget of Indonesian universities is still lacking in supporting Indonesian universities to become World Class Universities. The challenge that will become an obstacle in the future is the challenge of political and cultural variations within the Indonesian universities and the Indonesian government as the maker of regulations and policies that are used as guidelines in the field of education.

Thus, all universities are now defined not only in terms of national boundaries, but at the global level. In this sense, understanding what it means to be world class appears to be of paramount importance to the future vision and strategy of higher education institutions around the world. The case study research and relevant literature confirm that the drive towards world-class university status is the main hope in the future, with this encouragement, developing countries can engage and take advantage of the situation.

The transformation from IAIN to UIN is an important momentum for UIN Raden Fatah Palembang to continue to contribute, develop and advance education in the country in general and in South Sumatra in particular. It should be explained that UIN Raden Fatah Palembang in establishing a performance agreement with the Ministry of Religion of the Republic of Indonesia in early 2016 through logical and rational considerations and based on the needs and aspirations that developed in the academic community of UIN Raden Fatah Palembang.

To improve its international quality, apart from recruiting foreign students, UIN Raden Fatah Palembang can also do the following:

- Provide language training so that they are ready to compete at the regional level

- Encourage lecturers and education staff to improve their international skills

- Develop a curriculum that suits current needs

- Carry out more in-depth research on what is needed by the ASEAN community

- Cooperate with the government of South Sumatra Province in providing services and organizing international events. 


\section{REFEREENCES}

Angga Dunia Saputra. 2014. Asean Economic Community (AEC) 2015; Seberapa Siapkah Mahasiswa. Akses Online Himpunan Pengusaha Muda Indonesia. PT. Universitas Indonesia. Akses 9 September 2015.

Asosiasi Perguruan Tinggi Swasta (APTISI). 2014. Seminar Nasional Kesiapan Perguruan Tinggi Di Indonesia dalam Memasuki Masyarakat Ekonomi Asean (MEA) 2015. Akses online 14 September 2015.

BEM Universitas Pelita Harapan. (2014). Asean Economic Community (AEC) "Medan Tempur" Ekonomi Indonesia. Akses Online Universitas Pelita Harapan. Akses 15 September 2015.

Didik Ahmad Supadie. 2014. Peran dan Kesiapan Mahasiswa Menghadapi MEA 2015. Akses Online. Seminar BEM FAI UNISSULA.

Durkheim, E. (1898). 1973.“Individualism and the Intellectuals,”. Emile Durkheim: On morality and society.

George Ritzer, Douglas J. Goodman, (2010), Teori Sosiologi Modern, Jakarta: Kencana

Hamel, G., Prahalad, C. K., Thomas, H., \& O’Neal, D. (2005). Strategic flexibility. SPb.: Piter

Hinton, K. E. (2012). A practical guide to strategic planning in higher education (Vol. 7). USA: Society for College and University Planning.

Hinton, K. E. (2012). A practical guide to strategic planning in higher education (Vol. 7). USA: Society for College and University Planning.

Indi Widiarsih. 2014. Peran Mahasiswa Menghadapi AEC 2015. Akses online www.academia.edu. Akses 10 September 2015.

Lexy J. Moleong, 2005, Metodologi Penelitian Kualitatif,Bandung: Remaja Rosdakarya

Mastuhu, 2003, Menata Ulang Pemikiran Sistem Pendidikan Nasional dalam Abad 21, Yogyakarta: Safiria Ingaria Press.

Maunah, B. (2016). Pendidikan dalam Perspektif Struktural Fungsional. Cendekia: Jurnal Pendidikan dan Pembelajaran, 10(2)

Moleong, Lexy J., $\quad$ 2005, Metodologi Penelitian Kualitatif,Bandung: Remaja Rosdakarya.

Neilson, G. L., Martin, K. L., \& Powers, E. (2008). The secrets to successful strategy execution. Harvard business review, 86(6),

Neilson, G. L., Martin, K. L., \& Powers, E. (2008). The secrets to successful strategy execution. Harvard business review, 86(6)

Porter, M. E. (1996). What is strategy?. Harvard business review, 74(6)

Porter, M. E. (1996). What is strategy?. Harvard business review, 74(6)

Soetarno, 2004, Makalah Sumber Daya Pendidikan Dengan Pendekatan Sistem, Surakarta: UMS.

Spradley James, 1980, Participant Observation, New York, Holt, Rinehart and Winston. Sutopo, 2002, Metodologi Penelitian Kualitatif, Surakarta: Sebelas Maret University Press. Sutopo, 2002, Metodologi Penelitian Kualitatif, Surakarta: Sebelas Maret University Press Tilaar, HAR, 2002, Membenahi Pendidikan Nasional, Jakarta: Rineka Cipta.

Wahab, R. (2004), Mengkritisi sistem pendidikan nasional, aktualisasi otonomi pendidikan dan alokasi anggaran pendidikan. 